\title{
ANALISIS HUBUNGAN SIKAP DAN PENGETAHUAN TERHADAP KEPATUHAN PENGGUNAAN Fe PADA IBU HAMIL DI PUSKESMAS TIRTAMULYA
}

\author{
Cica Nurrohmah*, Diany Astuti, Maulana Yusuf Alkandahri \\ Fakultas Farmasi, Universitas Buana Perjuangan Karawang, Jawa Barat, Indonesia. \\ *Penulis Korespondensi: fm16.cicanurrohmah@mhs.ubpkarawang.ac.id
}

\begin{abstract}
ABSTRAK
Stunting merupakan masalah gizi kronis yang bersifat antargenerasi dan disebabkan oleh multifaktorial. Hasil studi membuktikan bahwa pengaruh faktor keturunan hanya berkontribusi sebesar $15 \%$, sementara unsur terbesar adalah terkait masalah asupan gizi, hormon pertumbuhan dan terjadinya penyakit infeksi berulang. Salah satu asupan gizi yang perlu diperhatikan ibu hamil adalah zat besi $(\mathrm{Fe})$. Tujuan penelitian untuk melihat hubungan sikap dan pengetahuan terhadap tingkat kepatuhan penggunaan Fe pada ibu hamil di Puskesmas Tirtamulya. Penelitian ini dilakukan dengan jenis penelitian analitik prospektif dengan pendekatan korelasi. Berdasarkan hasil penelitian di Puskesmas Tirtamulya yang telah diuji dengan menggunakan metode Chi-Square, terdapat hubungan yang signifikan pada Puskesmas Tirtamulya dengan nilai p-value $0,001(\mathrm{pv}<0,05)$ artinya, tingkat sikap memiliki hubungan dengan kepatuhan penggunaan $\mathrm{Fe}$ pada ibu hamil dan tingkat pengetahuan memiliki hubungan dengan kepatuhan penggunaan Fe pada ibu hamil.
\end{abstract}

Kata kunci: Stunting, Sikap, Pengetahuan, Kepatuhan, Fe (zat besi), Puskesmas

\section{ANALYSIS OF THE RELATIONSHIP BETWEEN ATTITUDES AND KNOWLEDGE OF COMPLIANCE WITH THE USE OF Fe IN PREGNANT WOMEN AT TIRTAMULYA MEDICAL CENTER}

\begin{abstract}
Stunting is a chronic malnutrition that is intergenerational and caused by multifactorial causes. The study results prove that heredity affects only contributed $15 \%$, while the biggest element was related to nutritional intake, growth hormone and repeated infection. One of the nutritional intake that should be noted by pregnant woment is iron $(\mathrm{Fe})$. The research objective is to see the relationship attitudes and knowledge of complience level against Fe use by pregnant women at Medical Center Tirtamulya. This study was conducted with a prospective analytical study with a correlation approach. Based on the results of research at Medical Center Tirtamulya which has been tested using the chi-square methode, there is a significant relationship at the Medical Center Tirtamulya with a p-value of 0,001 $(\mathrm{pv}<0,05)$ meaning that the level of attitude has a relationship with compliance with the use of $\mathrm{Fe}$ in pregnant women and the level of knowledge has a relationship with compliance with the use of Fe in pregnant women.
\end{abstract}

Keyword: Stunting, Attitude, Knowledge, Complience, Fe (iron), Medical Center 


\section{PENDAHULUAN}

Stunting atau balita pendek adalah masalah gizi kronis yang bersifat antargenerasi dan disebabkan oleh multifaktorial. Masyarakat di Indonesia sering kali beranggapan bahwa tinggi badan dipengaruhi oleh faktor keturunan, padahal persepsi masyarakat tentang hal ini tidak tepat. Pemerintah dan berbagai sektor terkait perlu melakukan tindak upaya yang cukup besar untuk meluruskan persepsi ini (Losong dan Adriani, 2017). Sikap merupakan reaksi atau respon yang masih tertutup dari seseorang terhadap stimulus atau objek (Utomo, 2017). Sedangkan pengetahuan adalah hasil penginderaan manusia, atau hasil tahu seseorang terhadap objek melalui indera yang dimilikinya (mata, hidung, telinga, dan sebagainya). Dengan sendirinya, pada waktu pengindraan sampai menghasilkan pengetahuan tersebut sangat dipengaruhi oleh intensitas perhatian dan persepsi terhadap objek. Sebagian besar penetahuan seseorang diperoleh melalui indera pendengaran (telinga), dan indera penglihatan (mata). Pengetahuan seseorang terhadap objek mempunyai intensitas atau tingkatan berbeda-beda (Dewi, 2011).

Data proporsi jumlah balita pendek di Asia tahun 2017, Asia Tenggara termasuk pada peringkat kedua dengan prevalensi tertinggi sebanyak $14,9 \%$. Data prevalensi balita stunting yang dikumpulkan World Health Organization (WHO), Indonesia termasuk ke dalam negara ketiga dengan prevalensi tertinggi di Regional Asia tenggara/South-East Asia Regional (SEAR). Rata-rata prevalensi balita stunting di indonesia tahun 2005-2017 adalah $36.4 \%$ (Kementerian Kesehatan RI, 2018). Kabupaten Karawang terdiri dari 30 kecamatan dan 309 desa yang mempunyai prevalensi stunting tinggi yaitu $34,87 \%$ hal tersebut menjadikan Kabupaten Karawang termasuk kedalam 100 Kota/Kabupaten di Jawabarat dengan pengutamaan stunting (Bappenas, 2018).

Data prevalensi stunting terjadi peningkatan pada tahun $2010(35,6 \%)$ dan 2007 (36,8\%) perbandingan peningkatan tersebut terangkum pada prevalensi stunting nasional di tahun 2013 yaitu $(37,2 \%)$. Banyak upaya yang telah dilakukan oleh pemerintah untuk mengurangi jumlah stunting di Indonesia. Hal ini dapat ditinjau dari menurunnya prevalensi pada balita stunting dari $37.2 \%$ (2013) menjadi 30,8\% (2018). Jumlah baduta stunting pun menurun dari 32,8\% (2013) menjadi 29,9\% (2018). Namun, 
jumlah penurunan tersebut masih jauh dari target yang diharapkan (Riskesdas, 2018).

Zat besi (Fe) sangat diperlukan oleh tubuh untuk pertumbuhan, membantu kerja berbagai macam enzim dalam tubuh, menanggulangi infeksi, membantu kerja usus untuk menetralisir zat-zat toksin dan yang paling penting adalah untuk pembentukan hemoglobin. Defisiensi zat besi merupakan defisiensi mikronutrien yang paling banyak terjadi di dunia dan dapat menyebabkan pertumbuhan dan perkembangan kognitif (Yuniasri dan Candra, 2016). Maka dari itu penelitian ini bertujuan untuk melihat hubungan sikap dan pengetahuan terhadap tingkat kepatuhan penggunaan Fe pada ibu hamil di Puskesmas Tirtamulya.

\section{METODE PENELITIAN}

Penelitian ini dilakukan dengan jenis penelitian analitik secara prospektif dengan pendekatan korelasi menggunakan metode chi-square, pengambilan data dengan cara penelitian observasional pada bulan mei-juli 2020 di Puskesmas Tirtamulya telah disetujui oleh responden sebanyak 146 ibu hamil dengan menggunakan Persetujuan Setelah Penjelasan (PSP) untuk ikut serta dalam penelitian. Perijinan etik telah dilakukan dengan nomor registrasi 0220030446 atau 639/UN6.KEP/EC/2020. Rumus besar sampel yang digunakan untuk penelitian ini adalah rumus slovin:

$$
\begin{gathered}
\mathrm{n}=\frac{\mathrm{N}}{1+\mathrm{N}\left(\mathrm{d}^{2}\right)} \\
\mathrm{n}=\frac{232}{1+232\left(0,05^{2}\right)} \\
\mathrm{n}=\frac{232}{1,58} \\
\mathrm{n}=146
\end{gathered}
$$

Peneliti mengambil data menggunakan kuesioner yang berisi soal tentang tingkat sikap, tingkat pengetahuan, dan tingkat kepatuhan penggunaan Fe. Kuesioner tersebut telah dilakukan uji validitas dan reabilitas. Uji validitas dilakukan kepada $20 \mathrm{ibu}$ hamil dengan menunjukkan hasil yang valid untuk setiap item pertanyaan $r>0,444$ dengan nilai croanbach alpha >0,6. Analisis data yang digunakan dalam penelitian ini adalah analisi univariat dan bivariat. Analisis univariat dilakukan untuk menggambarkan karakteristik masing-masing variabel bebas dan terikat. Analisis bivariat dilakukan untuk mengetahui hubungan antara variabel bebas dan variabel terikat dengan menggunakan analisis chi-square dengan batas kemaknaan 0,05. 
HASIL PENELITIAN

A. Data demografi ibu hamil di Puskesmas Tirtamulya adalah sebagai berikut:

1) Usia Mengindikasikan sebagian besar ibu hamil mengandung diusia berkisar antara 20-35 tahun dengan persentase sejumlah $83,6 \%$, walaupun masih ditemukan subjek yang mengandung di usia >35 tahun dengan persentase sejumlah $16,4 \%$.

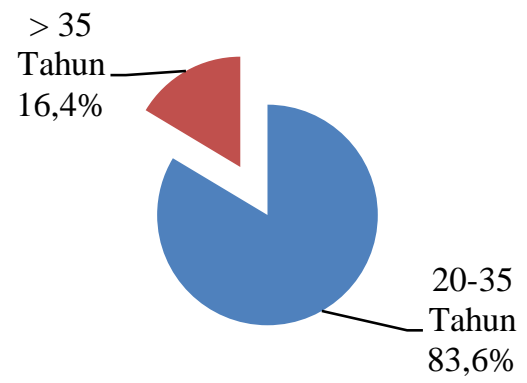

Gambar 1. Usia ibu hamil Puskesmas Tirtamulya.

2) Pendidikan

Mengindikasikan bahwa masih terdapat ibu hamil yang belum lulus wajib belajar 9 tahun dengan persentase sejumlah 55,5\%, sementara terdapat ibu hamil dengan tingkat pendidikan $\geq$ SMA dengan persentase sejumlah 44,5\%.

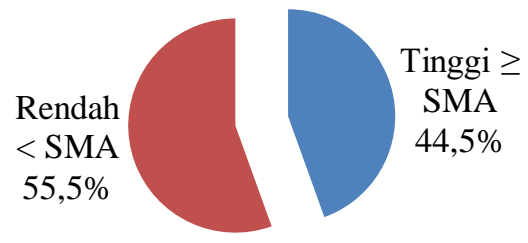

Gambar 2. Pendidikan ibu hamil di Puskesmas Tirtamulya.

3) Pekerjaan

Ibu hamil sebagian besar terdapat tidak bekerja dengan persentase sejumlah $90,4 \%$, sementara yang bekerja terdapat persentase dengan jumlah 9,6\%. 


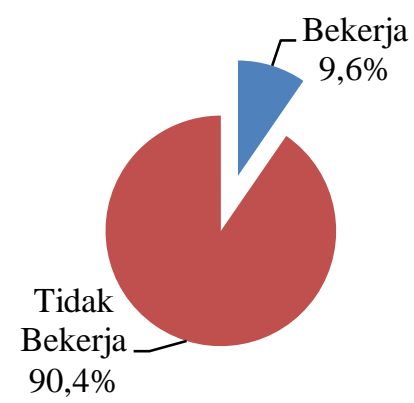

Gambar 3. Pekerjaan ibu hamil di Puskesmas Tirtamulya.

4) Lama Penggunaan Fe

Mengindikasikan bahwa terdapat jumlah persentase terbesar $43,2 \%$ ibu hamil dengan lama mengkonsumsi Fe 1-3 bulan, sisanya 37,7\% ibu hamil mengkonsumsi selama 4-6 bulan dan 19,2\% subjek mengkonsumsi Fe selama 79 bulan.

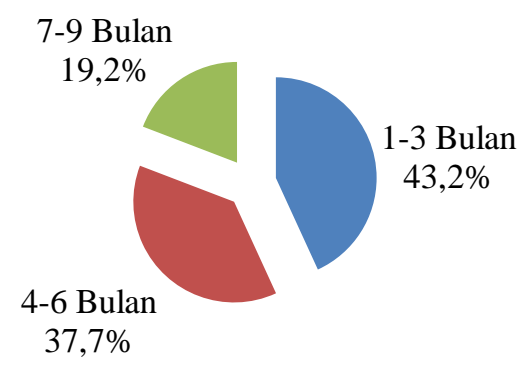

Gambar 4. Lama penggunaan Fe pada ibu hamil di Puskesmas Tirtamulya.

5) Paritas

Ditinjau menurut persentase jumlah paritas, paling banyak ibu hamil ialah primipara yaitu sejumlah $80 \%$ dan sisanya $20 \%$ ibu hamil dengan multipara.

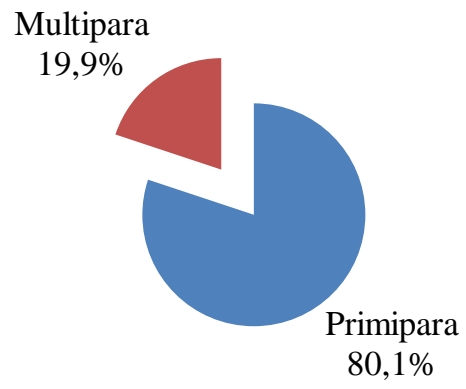

Gambar 5. Paritas ibu hamil di Puskesmas Tirtamulya.

6) Usia Kehamilan

Dari hasil survey terdapat persentase terbesar sejumlah 59,6\% pada ibu hamil yang sedang mengandung dengan kategori trimester II, sementara dengan persentase sejumlah 40,4\% pada ibu hamil yang sedang mengandung dengan kategori trimester III. 


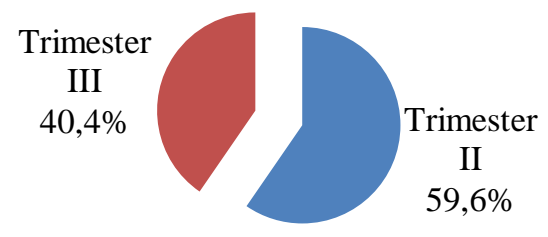

Gambar 6. Usia kehamilan ibu hamil di Puskesmas Tirtamulya.

7) Jumlah Anak

Dari hasil survey mengindikasikan sebagian besar ibu hamil mempunyai anak 1 dengan persentase sejumlah $78,8 \%$. Sisanya ibu hamil yang mempunyai anak $>1$ dengan persentase sejumlah $21,2 \%$.

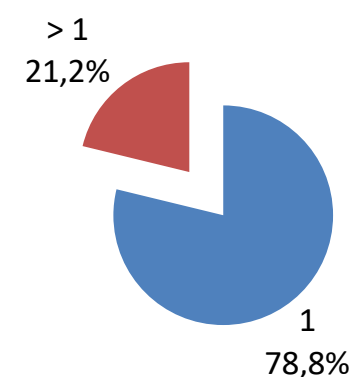

Gambar 7. Jumlah anak ibu hamil di Puskesmas Tirtamulya.

8) Tinggi Badan Bayi saat Lahir

Mayoritas ibu hamil dalam penelitian ini melahirkan bayi dengan tingi badan bayi saat lahir 45-50 cm dengan persentase sejumlah 73,5\%. Sementara sisanya $>50$ $\mathrm{cm}$ dengan persentase sejumlah $22,2 \%$ dan $<45 \mathrm{~cm}$ dengan jumlah persentase $4,2 \%$.

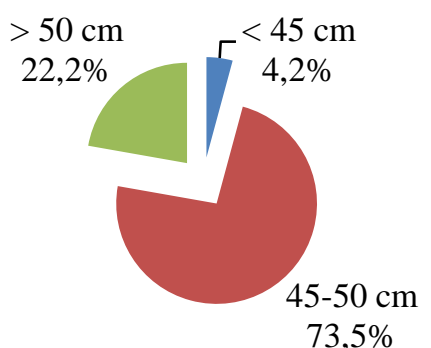

Gambar 8. Tinggi badan bayi saat lahir di Puskesmas Tirtamulya.

9) Tinggi Badan Anak Sekarang

Sedangkan untuk jumlah persentase tinggi anak ibu hamil sekarang mengindikasikan paling banyak dengan tinggi $>110 \mathrm{~cm}$ sejumlah $57,7 \%$, sisanya $100-110 \mathrm{~cm}$ dengan persentase $27,5 \%$ dan $<100 \mathrm{~cm}$ dengan persentase $14,8 \%$. 


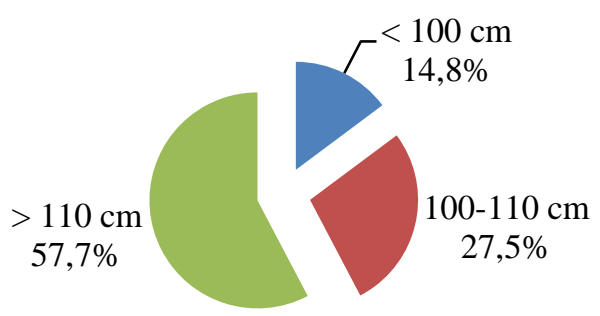

Gambar 9. Tinggi badan anak sekarang di Puskesmas Tirtamulya.

10) Usia Anak

Untuk jumlah persentase usia anak dari subjek paling banyak dengan usia $>5$ tahun memiliki persentase sejumlah $57,7 \%$.

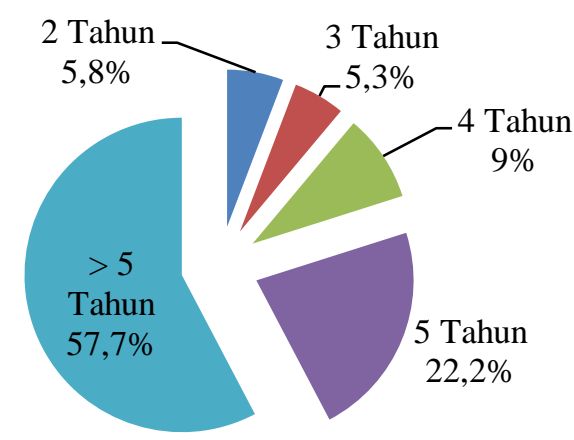

Gambar 10. Usia anak ibu hamil di Puskesmas Tirtamulya.

B. Data Tingkat Sikap, Tingkat Pengetahuan, dan Tingkat Kepatuhan Ibu Hamil di Puskesmas Tirtamulya adalah sebagai berikut:

1) Tingkat Sikap

Berdasarkan hasil penelitian mengindikasikan bahwa paling banyak ibu hamil memiliki tingkat sikap dengan kategori sikap baik memiliki persentase sejumlah $59,6 \%$. 


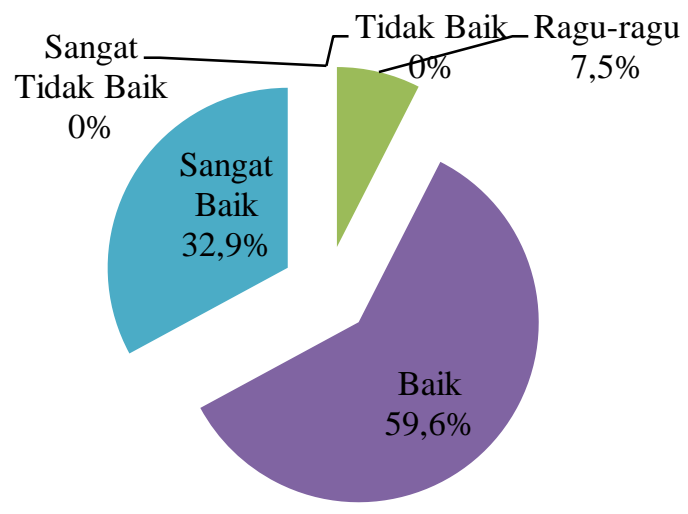

Gambar 11. Tingkat sikap ibu hamil di Puskesmas Tirtamulya.

2) Tingkat Pengetahuan

Berdasarkan hasil penelitian mengindikasikan bahwa paling banyak ibu hamil memiliki tingkat pengetahuaan dengan kategori pengetahuan tinggi memiliki persentase sejumlah $74,7 \%$.

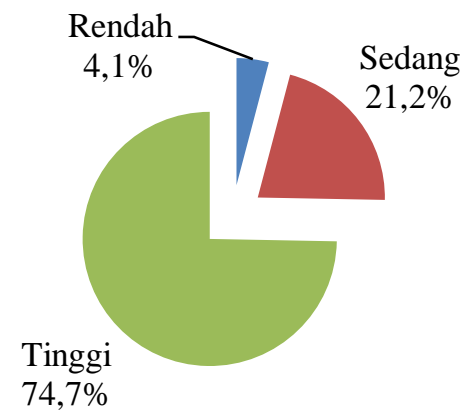

Gambar 12. Tingkat pengetahuan ibu hamil Puskemas Tirtamulya.

3) Tingkat Kepatuhan

Berdasarkan hasil penelitian mengindikasikan bahwa paling banyak ibu hamil memiliki tingkat kepatuhan dengan kategori kepatuhan rendah memiliki persentase sejumlah $52,1 \%$.

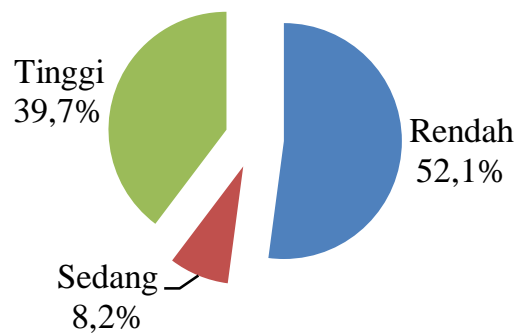

Gambar 13. Tingkat kepatuhan ibu hamil di Puskesmas Tirtamulya. 
C. Data Hubungan Tingkat Sikap dan Pengetahuan Terhadap Kepatuhan Penggunaan Fe di Puskesmas Tirtamulya

Berdasarkan hasil penelitian yang dilakukan dengan menggunakan kuesioner dan telah dilakukannya uji statistik dengan menggunakan metode uji chi-square diperoleh dengan hasil sebagai berikut:

Tabel 1. Tabulasi silang antara tingkat sikap terhadap tingkat kepatuhan penggunaan Fe di Puskesmas Tirtamulya

\begin{tabular}{|c|c|c|c|c|c|c|c|}
\hline \multirow{3}{*}{$\begin{array}{l}\text { Tingkat Sikap } \\
\text { tentang } \\
\text { penggunaan } \mathrm{Fe} \\
\text { terhadap } \\
\text { kepatuhan } \\
\text { penggunaan } \mathrm{Fe}\end{array}$} & \multicolumn{6}{|c|}{ Kepatuhan } & \multirow{3}{*}{ P-value } \\
\hline & \multicolumn{2}{|c|}{ Rendah } & \multicolumn{2}{|c|}{ Sedang } & \multicolumn{2}{|c|}{ Tinggi } & \\
\hline & $\mathbf{N}$ & $\%$ & $\mathbf{N}$ & $\%$ & $\mathbf{N}$ & $\%$ & \\
\hline Sangat Tidak- & - & - & - & - & - & - & \\
\hline Baik & & & & & & & \\
\hline Tidak Baik & - & - & - & - & - & - & \\
\hline Ragu-ragu & 9 & 11,8 & 2 & 16,7 & 0 & 0,0 & 0,001 \\
\hline Baik & 61 & 80,3 & 7 & 58,3 & 19 & 32,8 & \\
\hline Sangat Baik & 6 & 7,9 & 3 & 25,0 & 39 & 67,2 & \\
\hline Total & 76 & 100 & 12 & 100 & 58 & 100 & \\
\hline
\end{tabular}


Tabel 2. Tabulasi silang antara tingkat pengetahuan terhadap tingkat kepatuhan penggunaan Fe di Puskesmas Tirtamulya

\begin{tabular}{|c|c|c|c|c|c|c|c|}
\hline \multirow{3}{*}{$\begin{array}{l}\text { Tingkat } \\
\text { Pengetahuan } \\
\text { tentang } \\
\text { penggunaan } \mathrm{Fe} \\
\text { terhadap } \\
\text { kepatuhan } \\
\text { penggunaan } \mathrm{Fe}\end{array}$} & \multicolumn{6}{|c|}{ Kepatuhan } & \multirow{3}{*}{ P-value } \\
\hline & \multicolumn{2}{|c|}{ Rendah } & \multicolumn{2}{|c|}{ Sedang } & \multicolumn{2}{|c|}{ Tinggi } & \\
\hline & $\mathbf{N}$ & $\%$ & $\mathbf{N}$ & $\%$ & $\mathbf{N}$ & $\%$ & \\
\hline Rendah & 3 & 3,9 & 3 & 25,0 & 0 & 0,0 & \\
\hline Sedang & 29 & 38,2 & 2 & 16,7 & 0 & 0,0 & 0,001 \\
\hline Tinggi & 44 & 57,9 & 7 & 58,3 & 58 & 100 & \\
\hline Total & 76 & 100 & 12 & 100 & 58 & 100 & \\
\hline
\end{tabular}

\section{PEMBAHASAN}

Berdasarkan hasil penelitian dapat dilihat bahwa dari "76 ibu hamil yang memiliki kepatuhan rendah, sebagian besar memiliki tingkat sikap dengan kategori baik sebanyak $61(80,3 \%)$ ibu hamil". Dari 12 ibu hamil yang memiliki kepatuhan sedang, sebagian besar memiliki tingkat sikap dengan kategori baik sebanyak 7 (58,3\%) ibu hamil. Dan dari 58 ibu hamil yang memiliki kepatuhan tinggi, sebagian besar memiliki tingkat sikap dengan kategori sangat baik sebanyak $39(67,2 \%)$ ibu hamil. Sementara menurut hasil uji chi-square, skor $\mathrm{p}$-value $=0,001(\mathrm{p}<0,05)$ sehingga
H1 diterima artinya, tingkat sikap memiliki hubungan dengan kepatuhan penggunaan Fe pada ibu hamil.

Pada hasil penelitian ini sejalan dengan beberapa penelitian yang telah dilakukan sebelumnya, yaitu penelitian yang dilakukan di wilayah kerja Puskesmas Seberang Padang tahun 2013 yang memperlihatkan hasil uji statistik chi-square dengan diperoleh nilai $\mathrm{p}$-value sebesar 0,001 $(\mathrm{p}<0,05)$ yang artinya, terdapat hubungan bermakna antara sikap dan kepatuhan ibu hamil dalam mengkonsumsi tablet besi (Erwin et al., 2013). Maka ibu hamil yang memiliki sikap posistif akan cenderung bertindak 
patuh dalam penggunaan $\mathrm{Fe}$, sedangkan ibu hamil yang memiliki sikap negatif akan cenderung bertindak tidak patuh dan mengabaikan penggunaan Fe (Nurmala et al., 2018).

Menurut hasil analisa dapat diindikasikan bahwa dari 76 ibu hamil yang memiliki kepatuhan rendah, sebagian besar memiliki tingkat pengetahuan dengan kategori tinggi sebanyak 55 (100\%) ibu hamil. Dari 12 ibu hamil yang memiliki kepatuhan sedang, sebagian besar memiliki tingkat pengetahuan dengan kategori tinggi sebanyak 7 (58,3\%) ibu hamil dan "dari 58 ibu hamil dengan tingkat kepatuhan tinggi, sebagian besar juga memiliki tingkat pengetahuan dengan kategori tinggi yaitu sebanyak 58 (100\%) ibu hamil". Sementara menurut hasil uji chisquare, nilai $\mathrm{p}$-value $=0,000(\mathrm{p}<0,05)$ sehingga $\mathrm{H} 1$ diterima artinya, tingkat pengetahuan memiliki hubungan dengan kepatuhan penggunaan Fe pada ibu hamil.

Pada hasil penelitian ini sesuai dengan penelitian yang dilakukan di wilayah kerja Puskesmas Seberang Padang tahun 2013 yang menunjukkan hasil uji statistik chi-square diperoleh nilai $\mathrm{p}$-value sebesar $0,021 \quad(\mathrm{p}<0,05)$ bahwa pengetahuan merupakan salah satu faktor yang berhubungan dengan kepatuhan ibu hamil dalam mengkonsumsi Fe (Erwin et al., 2013).
Stunting mulai terjadi ketika janin masih dalam kandungan disebabkan oleh asupan makanan ibu selama kehamilan yang kurang bergizi. Akibatnya, gizi yang didapat anak dalam kandungan tidak mencukupi. Kekurangan gizi akan menghambat pertumbuhan bayi dan bisa terus berlanjut (Bingan, 2019). Pengetahuan yang dimiliki oleh ibu hamil akan berpengaruh terhadap perilakunya. Ibu hamil dengan pengetahuan gizi yang baik akan berusaha memberikan gizi yang cukup pula untuk diri sendiri dan janinnya (Nurmala et al., 2018).

\section{KESIMPULAN}

Berdasarkan hasil penelitian analisis hubungan sikap dan pengetahuan terhadap tingkat kepatuhan penggunaan $\mathrm{Fe}$ pada ibu hamil di Puskesmas Tirtamulya dapat disimpulkan bahwa terdapat hubungan yang signifikan pada Puskesmas Tirtamulya dengan nilai p-value 0,001 $(p<0,05)$ artinnya, tingkat sikap memiliki hubungan dengan kepatuhan penggunaan Fe pada ibu hamil dan tingkat pengetahuan memiliki hubungan dengan kepatuhan penggunaan Fe pada ibu hamil.

\section{DAFTAR PUSTAKA}

Bappenas. 2018. Daftar Wilayah Prioritas. Karawang.

Bingan, ECS. Hubungan Konsumsi Fe dengan Panjang Badan pada Anak Usia 12-24 Bulan. Media Informasi, 2019, 15(2): 115-120. 
Dewi, PMS. 2011. Hubungan Pengetahuan dan Sikap Penderita Tb Paru dengan Kepatuhan Minum Obat Antituberkulosis di Puskesmas Lidah Kulon Surabaya. Skripsi. Universitas Airlangga. Surabaya.

Erwin, RG., Machmud, R., dan Utama, BI. Hubungan Pengetahuan dan Sikap Ibu Hamil dengan Kepatuhan dalam Mengkonsumsi Tablet Besi di Wilayah Kerja Puskesmas Seberang Padang. Jurnal Kesehatan Andalas, 2017, 6(3): 596-601.

Losong, NHF., dan Adriani, M. Perbedaan Kadar Hemoglobin, Asupan Zat Besi, dan Zinc pada Balita Stunting dan Non Stunting. Amerta Nutr, 2017, 1(2): 117-123.

Nurmala, I., Rahman, F., Nugroho, A., Erlyani, N., Laily, N., dan Anhar, V. 2018. Promosi Kesehatan. Surabaya: Airlangga University Press.

Riskesdas. 2018. Riset Kesehatan Dasar. Kementerian Kesehatan RI. Jakarta.

Utomo, L. 2017. Analisis Sikap Pustakawan Referensi dalam Melayani Mahasiswa di Perpustakaan Universitas Muhammadiyah Semarang. Skripsi. Universitas Diponegoro. Semarang.

Yuniasri, EE., dan Candra, A. Pengaruh Suplementasi Seng dan Zat Besi terhadap Tinggi Badan Balita Usia 3-5 Tahun di Kota Semarang. Jurnal of Nutrition College, 2016, 5(4): 381-387. 